\title{
Dangerous neighborhood: saurophagy between syntopic Tropidurus lizards
}

\author{
Daniel Cunha Passos ${ }^{1,4}$, Felipe Augusto Correia Monteiro ${ }^{2}$ \& Carlos Henrique de Oliveira Nogueira ${ }^{3}$ \\ ${ }^{1}$ Universidade do Estado do Rio de Janeiro, Programa de Pós-Graduação em Ecologia e Evolução, \\ Rua São Francisco Xavier, 524, Pavilhão Haroldo Lisboa da Cunha, Sala 224, 20550-013, Rio de Janeiro, \\ RJ, Brazil. \\ ${ }^{2}$ Instituto Federal de Ciência, Educação e Tecnologia do Estado do Ceará, Jaguaribe, CE, Brazil. \\ ${ }^{3}$ Universidade Estadual do Norte Fluminense Darcy Ribeiro, Campos dos Goytacazes, RJ, Brazil. \\ ${ }^{4}$ Corresponding author: Daniel Passos,e-mail: biologodanielpassos@gmail.com
}

PASSOS, D.C., MONTEIRO, F.A.C., NOGUEIRA, C.H.O. Dangerous neighborhood: saurophagy between syntopic Tropidurus lizards. Biota Neotropica. 16(1): e20150062. http://dx.doi.org/10.1590/16760611-BN-2015-0062

\begin{abstract}
Saurophagy constitutes an important source of mortality among lizards and has been reported for the genus Tropidurus. However, the extension of this behavior remains unknown. Herein, we record the predation of $T$. jaguaribanus by its congener $T$. hispidus. This is the first report of saurophagy among different species of syntopic Tropidurus. Furthermore, whereas published records of saurophagy tend to be directed against juveniles, this case involved two adult individuals.

Keywords: Predation, mortality, agonistic interactions, Tropiduridae, Caatinga.
\end{abstract}

PASSOS, D.C., MONTEIRO, F.A.C., NOGUEIRA, C.H.O. Vizinhança perigosa: saurofagia entre lagartos Tropidurus sintópicos. Biota Neotropica. 16(1): e20150062. http://dx.doi.org/10.1590/1676-0611BN-2015-0062

Resumo: A saurofagia constitui uma importante fonte de mortalidade entre lagartos e tem sido reportada para o gênero Tropidurus. Contudo, a extensão deste comportamento permanece desconhecida. Neste estudo registramos a predação de T. jaguaribanus por seu congênere T. hispidus. Este é o primeiro caso de saurofagia entre diferentes espécies de Tropidurus sintópicos. Além disso, embora a saurofagia tenda a ser direcionada contra jovens, este caso envolveu dois indivíduos adultos. Palavras-chave: Predação, mortalidade, interações agonísticas, Tropiduridae, Caatinga.

\section{Introduction}

Predation constitutes one of the major pressures negatively affecting natural populations. In context of lizards, the predation by a sympatric lizard and even by the same species represent two important sources of mortality (Vitt 2000, Siqueira \& Rocha 2008). At first glance, the incidence of these kind of predatory events appeared to be infrequent, but cases of saurophagy and cannibalism among lizards are increasingly documented (Pincheira-Donoso 2012, Robbins et al. 2013).

Lizards of the genus Tropidurus are known to be ambush foragers with opportunistic feeding habits. Although their diet is primarily composed of arthropods, several species also feed on plant itens as well small vertebrates (Faria \& Araújo 2004, Van Sluys et al. 2004, Kolodiuk et al. 2010). Among the vertebrate preys of Tropidurus, there are consumption records of mammals (Gasparini \& Peloso 2007), frogs (Vitt et al. 1996, Kiefer et al. 2006, Ribeiro \& Freire 2009, Costa et al., 2010), but mainly of lizards. For instance, saurophagy was reported for $T$. hispidus (Spix, 1825) (Rojas-Runjaic et al. 2006, Costa et al. 2010, Zanchi et al. 2012), T. itambere Rodrigues, 1987 (Faria \& Araújo 2004), T. montanus Rodrigues, 1987 (Kiefer 1998), and T. torquatus (Wied, 1820) (Teixeira \& Giovanelli 1999, Galdino \& Van Sluys
2004, Kokubum \& Lemos 2004, Kiefer et al. 2006, Peloso \& Pavan 2007). Moreover, cannibalism was recorded in T. hispidus (Sales et al. 2011), T. hygomi Reinhardt \& Lütken, 1861 (Dias \& Rocha 2004, Kohlsdorf et al. 2004), T. montanus (Kiefer \& Sazima 2002), T. oreadicus Rodrigues, 1987 (Araujo 1987), and T. torquatus (Kiefer et al. 2006).

Despite saurophagic and cannibalistic behaviors had been relatively well documented for Tropidurus lizards, the extent of these events remains misunderstood. Furthermore, of all saurophagic records involving Tropidurus lizards as predators, none included syntopic congeners as prey. Herein, we expand the knowledge on saurophagy by providing the first record of predation of T. jaguaribanus Passos, Lima \& Borges-Nojosa, 2011 by T. hispidus.

\section{Material and Methods}

The observations were made during a field study on the geographical distribution of the species of the Tropidurus semitaeniatus group, at the vicinity of the Instituto Federal de Ciência, Educação e Tecnologia do Estado do Ceará - IFCE (552'59" S, 38 36'13" W, 137 m a.s.1., Datum: WGS 1984), Jaguaribe municipality, Ceará state, northeastern Brazil. The study area is located in a depression region between residual 
massifs along the middle course of the Jaguaribe River, where there are many rocky outcrops. This location is covered by secondary vegetation composed mainly of xerophytic shrubs and an ephemeral herbaceous stratum during the rainy season. The climate is semiarid and the environment is highly susceptible to desertification (Guerra et al. 2010).
Predatory event was video and photographically recorded in detail by two of us (DCP and FACM) about 5 meters from the lizards. After the end of the observations, both prey and predator were collected, fixed in $10 \%$ formalin, preserved in $70 \%$ ethanol, and deposited in the Coleção Herpetológica da Universidade Federal do Ceará (CHUFC L 5996 - T. jaguaribanus and
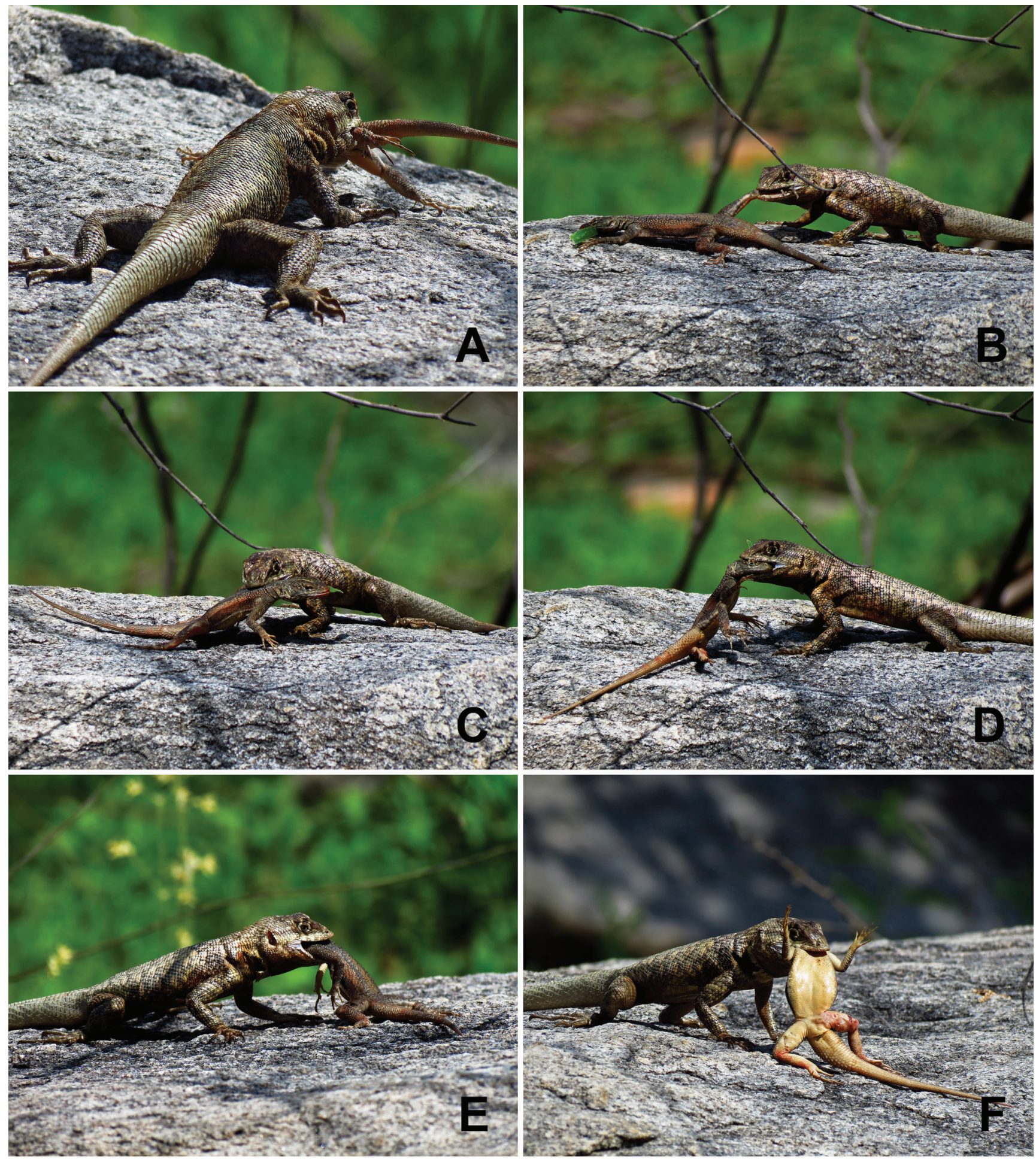

Figure 1. Saurophagic behavior of Tropidurus hispidus on Tropidurus jaguaribanus. (A) prey capture by the left hindlimb; (B) prey recapture by the right hind limb; (C) prey recapture by the thorax; (D) prey recapture by the head; (E) dorsal attempt to swallow the prey; (F) ventral attempt to swallow the prey. 
CHUFC L 5997 - T. hispidus) . In the lab, the snout-vent length (SVL) of lizards was measured with calipers (to nearest $0.01 \mathrm{~mm}$ ). An X-ray was made of the T. jaguaribanus specimen (VMI-Philips Compacto Plus $500-32 \mathrm{kV} / 0.03 \mathrm{mAs} / \mathrm{mA} \mathrm{100)}$ to evaluate its bone injuries. It was then dissected to diagnose its cause of death by one of us $(\mathrm{CHON})$, at the radiology sector at the Veterinary Hospital of the Universidade Estadual do Norte Fluminense Darcy Ribeiro.

\section{Results}

On the morning of 23 April 2015 at 09:14 a.m. an adult male Tropidurus hispidus (112.5 mm SVL) chased and caught an adult female of $T$. jaguaribanus $(76.4 \mathrm{~mm} \mathrm{SVL})$ by its left hind limb (Figure 1A). After a few seconds, the predator vigorously shook the prey still firmly held between its jaws, while the prey writhed and bit its head in unsuccessful attempts to escape. Thereafter, the predator briefly released the prey triggering its escape, but soon pursued and recaptured it again. This process involving release, pursuit and recapture happened several times, differing only in the part of the prey's body (e.g., right hindlimb, thorax, and head, respectively) bitten by the predator (Figure 1B-D). Only 26 minutes after the beginning of the observations we assumed the death of the prey, due to the absence of any reaction to the last release event. On that occasion, the predator kept right off and gently touched the prey. Prey manipulation and observation lasted some minutes, afterwards the predator began to swallow it. There were two attemps to swallow the prey, both head-first. Initially, the predator tried to swallow the prey dorsally (Figure 1E), but failed. Then, it turned the prey with belly up and tried to swallow it again (Figure 1F). However, the predator was not able to swallow entirely the prey. At 10:16 a.m., after almost an hour, the predator started to lose interest for the prey, and we shot it down with an airgun. Then, both lizards were collected, taken to the lab and deposited at the scientific collection of the Universidade Federal do Ceará.

The radiography showed multiple bone fractures throughout the prey's body (Figure 2) as follows: jaw (complete fracture of the left mandibular bone), right forelimb (luxation of the radioulnar and radiocarpal joints), left hind limb (transversal fracture of the femur), right hind limb (spiral fracture of the fibula). The necropsy also revealed several tegumentary perforations at the bite sites, lacerations and edemas in vicinity of the fractured bones, as well hemorrhagic areas in the femoral region of the left hind limb and in the tibial region of the right hind limb. In addition, the lizard's skull was smashed, estimated about $12 \%$ by comparing the photographic records of the beginning and end of the predatory event (head height 7.0 and $6.1 \mathrm{~mm}$, respectively). However, although the hypovolemic shock might be generally the cause of death in severely injured animals (Fighera et al. 2008), we were not able to accurately evaluate the seriousness of the cranial trauma due to the small body size of the prey, and so the causa mortis of the specimen could not be precisely determined.

\section{Discussion}

The Neotropical lizard Tropidurus hispidus has a wide geographical distribution, occurring in Caatinga semiarid and coastal areas in northeastern Brazil as well as in Amazonian savanna enclaves in northern South America (Carvalho 2013). As is know for most Tropidurus, this species feeds mainly on arthropods, but leaves, flowers and fruits also may compose its diet (Vitt 1995, Van Sluys 2004, Kolodiuk et al. 2010). Moreover, small vertebrates

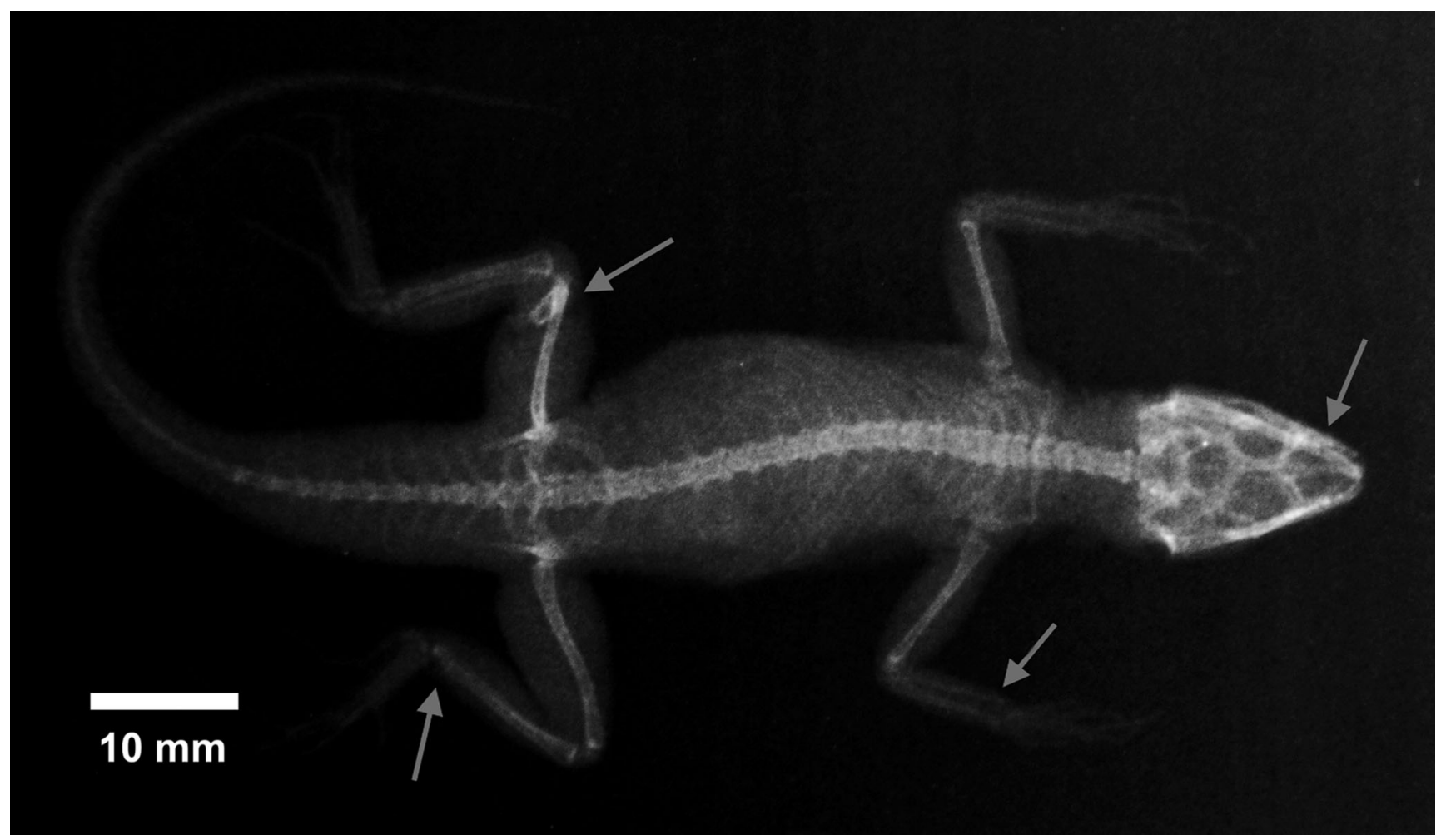

Figure 2. Radiography of an adult female Tropidurus jaguaribanus. The arrows indicate the multiple bone fractures. 
have been also reported among its prey, such as the frogs Elachistocleis ovalis (Schneider, 1799) (Vitt et al. 1996) and Scinax $x$-signatus (Spix, 1824) (Ribeiro \& Freire 2009), beyond the lizards Colobosaura modesta (Reinhardt and Lütken, 1862) (Costa et al. 2010), Cnemidophorus ocellifer (Spix, 1825) (Zanchi et al. 2012) and Norops auratus (Daudin, 1802) (Costa-Campos \& Souza 2013). Although T. hispidus is commonly found in sympatry with other congeners, as T. erythrocephalus Rodrigues 1987, T. hygomi and T. montanus (Rodrigues 1987), to our knowledge there is no record of congeneric saurophagy between syntopic Tropidurus species. Tropidurus hispidus and T. jaguaribanus live in syntopy on rocky outcrops along the Jaguaribe Valley in the state of Ceará (Passos et al. 2011) and although agonistic encounters between the species eventually occur, they usually tolerate the proximity to each other (Passos pers. obs.). Thus, this is the first record of T. jaguaribanus as prey of $T$. hispidus and the first report of congeneric saurophagy among different species of syntopic Tropidurus.

Tropidurus hispidus is one of the largest species of the torquatus group (Rodrigues 1987, Freitas \& Silva 2005), whilst T. jaguaribanus is the largest one of the semitaeniatus group (Passos et al. 2011, Passos et al. 2013). In general, juvenile lizards are more susceptible to predation in both saurophagic and cannibalistic interactions (Siqueira \& Rocha 2008). Their smaller relative size compared to adults, their higher relative abundance as well the lack of experience in avoid predators may explain this trend (Vitt 2000). In fact, the majority of records of saurophagy and cannibalism in $T$. hispidus were directed against juveniles (e.g. Sales et al. 2011) or species of smaller body size (e.g. Zanchi et al. 2012). However, the case reported herein involved adult individuals of two of the largest species of the genus Tropidurus. This itself would already be noteworthy, even more if added to the complex hunting behavior performed repeatedly by $T$. hispidus.

\section{Acknowledgements}

We thank Izamaro Araújo, director of the Instituto Federal de Ciência, Educação e Tecnologia do Estado do Ceará - Campus Jaguaribe, for the opportunity to work on the IFCE's property, and Jean Nixon for fieldwork assistance. We also thank Helena Hokamura, head of radiology sector from Veterinary Hospital of Universidade Estadual do Norte Fluminense Darcy Ribeiro, for logistical support and the radiological analysis. We are grateful to Daniel Cassiano Lima and Laís Feitosa Machado for the critical review of a previous version of this manuscript. We are also grateful to Gunther Köhler and an anonymous referee for the valuable suggestions to this paper. DCP is funded by a Doctor's degree scholarship from the Coordenação de Aperfeiçoamento de Pessoal de Nível Superior - CAPES. The collecting permit 42552-4 was granted by the Instituto Chico Mendes de Conservação da Biodiversidade - ICMBio.

\section{References}

ARAÚJO, A.F.B. 1987. Comportamento alimentar dos lagartos: o caso dos Tropidurus do grupo torquatus da Serra dos Carajás, Pará (Sauria: Iguanidae). An. Etol. 5:203-234.

CARVALHO, A.L.G. 2013. On the distribution and conservation of the South American lizard genus Tropidurus Wied-Neuwied, 1825 (Squamata: Tropiduridae). Zootaxa 3640:042-056, http://dx.doi.org/10.11646/ zootaxa.3640.1.3.

COSTA-CAMPOS, C.E. \& SOUZA, N.S. 2013. Tropidurus hispidus (Peters' Lava Lizard). Saurophagy. Herpetol. Rev. 44:215-216.
COSTA, J.C.L., MANZANI, P.R., BRITO, M.P.L. \& MACIEL, A.O. 2010. Tropidurus hispidus (Calango). Prey. Herpetol. Rev. 41:87.

DIAS, E.J.R. \& ROCHA, C.F.D. 2004. Tropidurus hygomi (NCN). Juvenile predation. Herpetol. Rev. 35:398-399.

FARIA, R.R. \& ARAÚJO, A.F.B. 2004. Syntopy of two Tropidurus lizard species (Squamata: Tropiduridae) in a rocky Cerrado habitat in Central Brazil. Braz. J. Biol. 64:775-786, http://dx.doi.org/10.1590/ S1519-69842004000500007.

FIGHERA, R.A., SILVA, M.C., SOUZA, T.M., BRUM, J.S., KOMMERS, G.D., GRAÇA, D.L., IRIGOYEN, L.F. \& BARROS, C.S.M. 2008. Aspectos patológicos de 155 casos fatais de cães atropelados por veículos automotivos. Cienc. Rural 38:1375-1380.

FREITAS, M.A. \& SILVA, T.F.S. 2005. Guia ilustrado: a herpetofauna da Mata Atlântica nordestina. Editora USEB, Pelotas.

GALDINO, C.A.B. \& VANSLUYS,M. 2004. Tropidurus torquatus (Collared Lizard, Calango). Saurophagy. Herpetol. Rev. 35:173.

GASPARINI, J.L. \& PELOSO, P.L. 2007. Tropidurus torquatus (Brazilian Collared Lizard). Diet. Herpetol. Rev. 38:464.

GUERRA, M.D.F., SOUZA, M.J.N. \& LUSTOSA, J.P.G. 2010. Desertificação em áreas semiáridas do Nordeste Brasileiro: O caso do município de Jaguaribe, Ceará. Rev. Geo. 2:67-80.

KIEFER, M.C. 1998. Anotosaura brachylepis (NCN). Predation. Herpetol. Rev. 29:41.

KIEFER, M.C. \& SAZIMA, I. 2002. Tropidurus montanus (NCN). Cannibalism. Herpetol. Rev. 33:136.

KIEFER, M.C., SIQUEIRA, C.C., VAN SLUYS, M. \& ROCHA, C.F.D. 2006. Tropidurus torquatus (Collared Lizard, Calango). Prey. Herpetol. Rev. 37:475-476.

KOHLSDORF, T., GODOY, C. \& NAVAS, C.A. 2004. Tropidurus hygomi $(\mathrm{NCN})$. Cannibalism. Herpetol. Rev. 35:398.

KOKUBUM, M.C. \& LEMOS, F.G. 2004. Tropidurus torquatus (Calango). Saurophagy. Herpetol. Rev. 35:270-271.

KOLODIUK, M.F., RIBEIRO, L.B. \& FREIRE, E.M.X. 2010. Diet and foraging behavior of two species of Tropidurus (Squamata, Tropiduridae) in the Caatinga of northeastern Brazil. South Am. J. Herpetol. 5:35-44, http://dx.doi.org/10.2994/057.005.0104.

PASSOS, D.C., LIMA, D.C. \& BORGES-NOJOSA, D.M. 2011. A new species of Tropidurus (Squamata, Tropiduridae) of the semitaeniatus group from a semiarid area in Northeastern Brazil. Zootaxa 2930:60-68.

PASSOS, D.C., LIMA, D.C. \& BORGES-NOJOSA, D.M. 2013. Clutch size, incubation time and hatchling morphometry of the largest known Tropidurus of the semitaeniatus group (Squamata, Tropiduridae), in a semi-arid area from northeastern Brazil. Herpetol. Bul. 123:23-25.

PELOSO, P.L. \& PAVAN, S.E. 2007. Cnemidophorus nativo (NCN). Predation. Herpetol. Rev. 38:451-452.

PINCHEIRA-DONOSO, D. 2012. Intraspecific predation in the Liolaemus lizard radiation: a primer. Anim. Biol. 62:277-287, http://dx. doi.org/10.1163/157075611X618219.

RIBEIRO, L.B. \& FREIRE, E.M.X. 2009. Tropidurus hispidus (NCN). Frog predation. Herpetol. Rev. 40:228-228.

ROBBINS, T.R., SCHREY, A., MCGINLEY, S. \& JACOBS, A. 2013. On the incidences of cannibalism in the lizard genus Sceloporus: updates, hypotheses, and the first case of siblicide. Herpetol. Notes 6:523-528.

ROJAS-RUNJAIC, F.J.M., FERRER, A., RIVAS, G.A. \& MONTERO, Z.A. 2006. Tropidurus hispidus. Saurophagy. Herpetol. Rev. 37:474.

RODRIGUES, M.T. 1987. Sistemática, ecologia e zoogeografia dos Tropidurus do grupo torquatus ao Sul do rio Amazonas (Sauria, Iguanidae). Arq. Zool. 31:105-230.

SALES, R.F.D., JORGE, J.S., RIBEIRO, L.B. \& FREIRE, E.M.X. 2011. A case of cannibalism in the territorial lizard Tropidurus hispidus (Squamata: Tropiduridae) in Northeast Brazil. Herpetol. Notes 4:265-267.

SIQUEIRA, C.C. \& ROCHA, C.F.D. 2008. Predation by lizards as a mortality source for juvenile lizards in Brazil. South Am. J. 
Herpetol. 3:82-87, http://dx.doi.org/10.2994/1808-9798(2008)3[82: PBLAAM]2.0.CO;2.

TEIXEIRA, R.L. \& GIOVANELLI, M. 1999. Ecologia de Tropidurus torquatus (Sauria: Tropiduridae) da restinga de Guriri, São Mateus, ES. Rev. Bras. Biol. 59:11-18, http://dx.doi.org/10.1590/ S0034-71081999000100002.

VAN SLUYS, M., ROCHA, C.F.D., VRCIBRADIC, D., GALDINO, C.A.B. \& FONTES A.F. 2004. Diet, activity and microhabitat use of two syntopic Tropidurus species (Lacertilia: Tropiduridae) in Minas Gerais, Brazil. J. Herpetol. 38:606-611.
VITT, L.J. 1995. The ecology of tropical lizards in the caatinga of northeast Brazil. Oklah. Mus. Nat. Hist. 1:1-29.

VITT, L.J. 2000. Ecological consequences of body size in neonatal and small-bodied lizards in the Neotropics. Herpetol. Monogr. 14:388-400.

VITT, L.J., ZANI, P.A. \& CALDWELL, J.P. 1996. Behavioural ecology of Tropidurus hispidus on isolated rock outcrops in Amazonia. J. T. Ecol. 12:81-101, http://dx.doi.org/10.1017/S0266467400009329.

ZANCHI, D., PASSOS, D.C. \& BORGES-NOJOSA, D.M. 2012. Tropidurus hispidus (Calango). Saurophagy. Herpetol. Rev. 43:141-142. 